\title{
Perancangan Aplikasi Pemilihan Texapon Dalam Pembuatan Sabun Cair Dengan Menerapkan Metode Analytical Hierarchy Process
}

\author{
Fristi Riandari \\ Teknik Informatika, STMIK Pelita Nusantara Medan, Jl. Iskandar Muda No.1 Medan \\ Email : fristy.rianda@gmail.com
}

\begin{abstract}
Keberhasilan sebuah produk dari perusahaan tergantung dari kwalitas bahan baku. dan sulitnya dalam menentukan bahan baku secara cepat dan membutuhkan waktu yang lama. Oleh karena itu di perlukan untuk mengatasi masalah tersebut adalah sebuah Sistem Pendukung Keputusan untuk memilih Texapon dalam pembuatan sabun cair dengan metode AHP.Untuk mengetahui hal tersebut, maka akan dilakukan suatu metode pengambilan keputusan multikriteria dengan cara memecahkan situasi kompleks dan tidak terstruktur kedalam bagian-bagian dan menyusunnya dalam hierarki.Dengan menggunakan metode AHP pada SPK maka penentuan Texapon dalam pembuatan sabun cair dapat dihitung berdasarkan perhitungan dari bobot kriteria masing-masing, sehingga dapat memilih Texapon dalam pembuatan sabun cair di dalam perusahaan dapat dilakukan secara cepat.
\end{abstract}

Kata Kunci : Sistem Pendukung Keputusan, Pemilihan Texapon, Metode AHP

\section{Pendahuluan}

Texapon dengan nama lain Sodium Lauryl Sulfat/Sodium Laureth adalah bahan yang digunakan untuk pembuatan sabun cair. Yang berfungsi sebagai pencipta busa, mengangkat lemak dan kotoran.

Dalam menetukan pengambilan keputusan pemilihan Texapon yang baik dan benar, banyak sekali kriteriakriteria yang harus dilihat dari banyaknya produk Texapon yang beredar di pasaran saat ini. yaitu salah satu faktor menentukan kualitas dari produk tersebut dalam keberhasilan peningkatan produktifitas hasil produksi sabun cair. Secara empiris, pemanfaatan Texapon sebagai salah satu komponen teknologi telah memberikan kontribusi yang besar dalam peningkatan kualitas pembuatan sabun cair.

Untuk mengatasi permasalahan tersebut di atas, maka diperlukan suatu Sistem Pendukung Keputusan dengan menggunakan metode AHP (Analytical Hierarchy Process). Model sistem pendukung keputusan ini akan menguraikan masalah multi faktor atau multi kreteria yang kompleks menjadi suatu hirarki, hirarki didefenisikan sebagai sesuatu refresentasi dari sebuah permasalahan yang kompleks dalam suatu struktur tujuan, yang diikuti level faktor, kriteria, dan seterusnya ke bawah hingga level terakhir. Sehingga dapat disimpulkan bahwa metode AHP (Analytical Hierarchy Process) dapat bekerja dengan baik.

\section{Landasan Teori}

\subsection{Sistem Pendukung Keputusan (SPK)}

Sistem pendukung keputusan merupakan sistem informasi interaktif yang menyediakan informasi, pemodelan dan memanipulasi data. Sistem itu digunakan untuk membantu pengambilan keputusan dalam situasi yang semiterstruktural dan situasi yang tidak terstruktur dimana tak seorang pun tahu sacara pasti bagaimana keputusan seharusnya dibuat (Riyani, Awang Harsa Kiradalaksana dan Ahmad Rofiq Hakim, 2010 ).

Sistem pendukung keputusan biasanya dibangun untuk mendukung solusi atas suatu masalah atau untuk mengevaluasi suatu peluang. Sistem pendukung keputusan yang seperti itu disebut aplikasi Sistem pendukung keputusan. Aplikasi Sistem pendukung keputusan digunakan dalam pengambilan keputusan. Aplikasi menggunakan CBIS (Computer Based Information System) yang fleksibel, interaktif, dan dapat diadaptasi,yang dikembangkan untuk mendukung solusi atas masalah manajemen spesifik yang tidak terstruktur.

Aplikasi Sistem pendukung keputusan menggunakan data, memberikan antar muka pengguna yang mudah,dan dapat menggabungkan pemikiran pengambilan keputusan. Sistem pendukung keputusan lebih ditujukan untuk mendukung manajemen dalam melakukan pekerjaan yang bersifat analitis dalam situasi yang kurang terstruktur dan dengan kriteria yang kurang jelas. 
Sistem pendukung keputusan tidak dimaksudkan unutk mengotomatisaikan pengambilan keputusan, tetapi memberikan perangkat interaktif yang memungkinkan pengambilan keputusan untuk melakukan berbagai analisis menggunakan model-model yang tersedia. Tujuan dari DSS adalah :

1. Membantu manajer dalam pengambilan keputusan atas masalah semi- terstruktur.

2. Memberikan dukungan atas pertimbangan manajer dan bukannya dimaksudkan untuk menggantikan fungsi manajer.

3. Meningkatkan efektifitas keputusan yang diambil lebih daripada perbaikan efisiensinya.

4. Kecepatan komputasi. Komputer memungkinkan para pengambil keputusan untuk melakukan banyak komputansi secara cepat dengan biaya rendah.

5. Peningkatan produktivitas.

6. Dukungan kualitas.

7. Berdaya saing.

8. Mengatasi keterbatasan kognitif dalam pemrosesan dan penyimpanan.

\subsection{FMADM (FuzzyMultiple Attribute Decission Making )}

FMADM ( FuzzyMultiple Attribute Decission Making ) adalah metode yang di gunakan untuk mencari alternatif optimal dari sejumlah alternatif dengan kriteria tertentu. Inti dari FMADM adalah menentuka nilai bobot untuk setiap atribut, kemudian di lanjutkan dengan proses prankingan yang akan menyeleksi alternatif yang sudah di berikan pada dasarnya, ada 3 pendekatan untuk mencari nilai bobot atribut, yaitu pendekatan subyektif, pendekatan obyektif dan pendekatan integrasi antara subyektif dan obyektif. ( Kusumadewi, 2007 ).

Ada beberapa metode yang dapat digunakan untuk menyelesaikan masalah FMADM, antara lain :

1. Simple Additive Weighting Method (SAW).

2. Weighted Product (WP).

3. ELECTRE.

4. Technique For Order Preference by Similarity to Ideal Solution (TOPSIS).

5. Analitic Hierarchy Process (AHP).

\subsection{Algoritama FMADM}

Algoritma FMADM (FuzzyMultiple Attribute Decission Making) adalah :

1. Memberikan nilai alternatif (Ai) pada setiap kriteria $(\mathrm{Cj})$ yang di tentukan, dimana nilai tersebut di peroleh berdasarkan nilai crisp; $i=1,2, \ldots m$ dan $j=1,2, . ., n$.

2. Memberikan nilai bobot yang juga didapatkan berdasarkan nilai crisp.

3. Melakukan normalisasi matriks dengan cara menghitung nilai ranting kinerja ternormalisasi (rij) dari alternatif $\mathrm{Ai}$ pada atribut $\mathrm{Cj}$ bedasarkan persamaan yang di sesuaikan dengan jenis atribut (atribut keuntungan/benefit= MAKSIMUM atau atribut biaya/cost= MINIMUM). Apabila berupa atribut keuntungan maka nilai crisp (Xij) dari setiap kolom atribut di bagi dengan nilai crispMAX(MAX Xij) dari tiap kolom, sedangkan untuk atribut biaya, nilai crisp MIN (MIN Xij) dari tiap kolom atribut di bagi dengan nilai crisp (Xij) setiap kolom.

4. Melakukan proses perankingan dengan cara mengalikan matriks ternormalisasi (R) dengan nilai bobot.

5. Menentukan nilai preferensi untuk setiap alternatif (Vi) dengan cara menjumlahkan hasil kali antara matriks ternormalisasi (R) dengan nilai bobot nilai Vi yang lebih besar mengindikasikan bahwa alternatif Ai lebih terpilih. ( Kusumadewi, 2007 ).

\subsection{Analytical Hierarchy Process (AHP)}

Analytical Hierarchy Process (AHP) merupakan suatu model pendukung keputusan yang dikembangkan oleh Thomas L. Saaty. Model pendukung keputusan ini akan menguraikan masalah multi faktor atau multi kriteria yang kompleks menjadi suatu hirarki, menurut Saaty, hirarki didefinisikan sebagai suatu representasi dari sebuah permasalahan yang kompleks dalam suatu struktur multi level dimana level pertama adalah tujuan, yang diikuti level faktor, kriteria, sub kriteria, dan seterusnya ke bawah hingga level terakhir dari alternatif. Dengan hirarki, suatu masalah yang kompleks dapat diuraikan ke dalam kelompok-kelompoknya yang kemudian diatur menjadi suatu bentuk hirarki sehingga permasalahan akan tampak lebih terstruktur dan sistematis. sering digunakan sebagai metode pemecahan masalah dibanding dengan metode yang lain karena alasan-alasan sebagai berikut:

1. Struktur yang berhirarki, sebagai konsekuesi dari kriteria yang dipilih, sampai pada subkriteria yang paling dalam.

2. Memperhitungkan validitas sampai dengan batas toleransi inkonsistensi berbagai kriteria dan alternatif yang dipilih oleh pengambil keputusan. Memperhitungkan daya tahan output analisis sensitivitas pengambilan keputusan. (Kadarsyah Suryadi dan Ali Ramdhani, 2010) 
Dalam metode Analytical Hierarchy Process dilakukan langkah-langkah sebagai berikut (Kadarsyah Suryadi dan Ali Ramdhani, 2010) :

1. Mendefinisikan masalah dan menentukan solusi yang diinginkan.

Dalam tahap ini penulis berusaha menentukan masalah yang akan penulis pecahkan secara jelas, detail dan mudah dipahami. Dari masalah yang ada penulis coba tentukan solusi yang mungkin cocok bagi masalah tersebut. Solusi dari masalah mungkin berjumlah lebih dari satu. Solusi tersebut nantinya penulis kembangkan lebih lanjut dalam tahap berikutnya.

2. Membuat struktur hierarki yang diawali dengan tujuan utama.

Setelah menyusun tujuan utama sebagai level teratas akan disusun level hirarki yang berada di bawahnya yaitu kriteria-kriteria yang cocok untuk mempertimbangkan atau menilai alternatif yang penulis berikan dan menentukan alternatif tersebut. Tiap kriteria mempunyai intensitas yang berbeda-beda. Hirarki dilanjutkan dengan subkriteria (jika mungkin diperlukan).

3. Membuat matrik perbandingan berpasangan yang menggambarkan kontribusi relatif atau pengaruh setiap elemen terhadap tujuan atau kriteria yang setingkat di atasnya. Matriks yang digunakan bersifat sederhana, memiliki kedudukan kuat untuk kerangka konsistensi, mendapatkan informasi lain yang mungkin dibutuhkan dengan semua perbandingan yang mungkin dan mampu menganalisis kepekaan prioritas secara keseluruhan untuk perubahan pertimbangan. Pendekatan dengan matriks mencerminkan aspek ganda dalam prioritas yaitu mendominasi dan didominasi. Perbandingan dilakukan berdasarkan judgment dari pengambil keputusan dengan menilai tingkat kepentingan suatu elemen dibandingkan elemen lainnya. Untuk memulai proses perbandingan berpasangan dipilih sebuah kriteria dari level paling atas hirarki misalnya $\mathrm{K}$ dan kemudian dari level di bawahnya diambil elemen yang akan dibandingkan misalnya E1,E2,E3,E4,E5.

4. Melakukan Mendefinisikan perbandingan berpasangan sehingga diperoleh jumlah penilaian seluruhnya sebanyak n x [(n-1)/2] buah, dengan $\mathrm{n}$ adalah banyaknya elemen yang dibandingkan. Hasil perbandingan dari masing-masing elemen akan berupa angka dari 1 sampai 9 yang menunjukkan perbandingan tingkat kepentingan suatu elemen. Apabila suatu elemen dalam matriks dibandingkan dengan dirinya sendiri maka hasil perbandingan diberi nilai 1. Skala 9 telah terbukti dapat diterima dan bisa membedakan intensitas antar elemen. Hasil perbandingan tersebut diisikan pada sel yang bersesuaian dengan elemen yang dibandingkan. Skala perbandingan perbandingan berpasangan bisa dilihat di bawah:

a. 1 berarti kedua elemen sama pentingnya, Dua elemen mempunyai pengaruh yang sama besar

b. 3 berarti elemen yang satu sedikit lebih penting daripada elemen yanga lainnya, Pengalaman dan penilaian sedikit menyokong satu elemen dibandingkan elemen yang lainnya

c. 5 berarti elemen yang satu lebih penting daripada yang lainnya, Pengalaman dan penilaian sangat kuat menyokong satu elemen dibandingkan elemen yang lainnya

d. 7 berarti satu elemen jelas lebih mutlak penting daripada elemen lainnya, Satu elemen yang kuat disokong dan dominan terlihat dalam praktek.

e. 9 berarti satu elemen mutlak penting daripada elemen lainnya, Bukti yang mendukung elemen yang satu terhadap elemen lain memiliki tingkat penegasan tertinggi yang mungkin menguatkan.

f. 2,4,6,8 berarti nilai-nilai antara dua nilai pertimbangan-pertimbangan yang berdekatan, Nilai ini diberikan bila ada dua kompromi di antara 2 pilihan Kebalikan = Jika untuk aktivitas i mendapat satu angka dibanding dengan aktivitas $\mathrm{j}$, maka $\mathrm{j}$ mempunyai nilai kebalikannya dibanding dengan $\mathrm{i}$

5. Menghitung nilai eigen dan menguji konsistensinya. Jika tidak konsisten maka pengambilan data diulangi.

6. Mengulangi langkah 3,4, dan 5 untuk seluruh tingkat hirarki.

7. Menghitung vektor eigen dari setiap matriks perbandingan berpasangan yang merupakan bobot setiap elemen untuk penentuan prioritas elemen-elemen pada tingkat hirarki terendah sampai mencapai tujuan. Penghitungan dilakukan lewat cara menjumlahkan nilai setiap kolom dari matriks, membagi setiap nilai dari kolom dengan total kolom yang bersangkutan untuk memperoleh normalisasi matriks, dan menjumlahkan nilai-nilai dari setiap baris dan membaginya dengan jumlah elemen untuk mendapatkan rata-rata.

8. Memeriksa konsistensi hirarki. Adapun yang diukur dalam Analytical Hierarchy Process adalah rasio konsistensi dengan melihat index konsistensi. Konsistensi yang diharapkan adalah yang mendekati sempurna agar menghasilkan keputusan yang mendekati valid. Walaupun sulit untuk mencapai yang sempurna, rasio konsistensi diharapkan kurang dari atau sama dengan $10 \%$.

Rumus Untuk Menentukan Rasio Konsistensi (CR)

Indeks konsistensi dari matriks berordo $\mathrm{n}$ dapat diperoleh dengan rumus :

$\lambda$ maksimum $-\boldsymbol{n}$

$C I=$

$$
n-1
$$




\section{Keterangan:}

$\lambda$ max $=$ Maximum Eigen Value

$\mathrm{N} \quad=$ Ukuran Matriks

CR = Cossistency Ratio

$C I=$ Cossistency Index

IR $=$ Index Random Cossistency

1. Hitung konsistensi indeks $(C I)$ dengan rumus $C I=(\lambda \max -n)$

2. Hitung rasio konsistensi / Consistency Ratio $(C R)$

$\lambda_{\max }=$ jumlah elemen pada matriks $\mathrm{Y}$

$$
\mathrm{N}
$$

a. Menghitung nilai Consistency Index (CI)

$\mathrm{CI}=\lambda_{\max }-\mathrm{N}$

b. Menghitung Consistency Ratio (CR)

$\mathrm{CR}=\mathrm{CI}$

Random Index (tabel)

CI/RC

3. Memeriksa konsistensi hirarki. Jika nialinya lebih dari 10\%. Maka penilaian data judgemen harus diperbaiki. Namun jika ratio konsistensi $(C R / I R)$ kurang atau sama dengan 0.1 , maka hasil perhitungan bisa dinyatakan benar.

CR dirumuskan :

$$
C R=\frac{C I}{C R}
$$

\section{Implementasi}

\subsection{Algoritma}

Algoritma adalah suatu cara yang digunakan untuk memperoleh/ menerangkan suatu keadaan tertentu sehingga bisa lebih dimengerti atau menunjukkan langkah-langkah penyelesaian suatu masalah. Pada umumnya algoritma kurang lebih sama dengan prosedur yang sering dilakukan.

Algoritma memegang peranan penting dalam bidang pemrograman, karena pentingnya suatu algoritma, sehingga perlu dipahami konsep dasar algoritma. Algoritma banyak membantu dalam memahami konsep logika pemrograman. Apabila untuk seseorang melakukan suatu algoritma sehingga dapat membuat algoritma, agar bagaimana sistem yang dibangun dapat berjalan dengan baik.

Adapun urutan langkah langkah dalam menyelesaikan penentuan seleksi dengan metode Analitycah Hierarcy Process adalah sebagai berikut:

Input :

$$
\begin{aligned}
& \text { ID } \nabla \text { identitas } \\
& \mathrm{K} 1 \otimes \\
& \mathrm{Ki} \text { array [1...5] of kriteria: }
\end{aligned}
$$

Output :

$$
\text { W } \otimes \text { hasil akhir }
$$

Proses :

\{ Matriks Perbandingan Kriteria \}

For $\mathrm{i}=1$ to 5

$\mathrm{K} 1 \otimes(\mathrm{K} 1 / \mathrm{K} 1),(\mathrm{K} 1 / \mathrm{K} 2),(\mathrm{K} 1 / \mathrm{K} 3),(\mathrm{K} 1 / \mathrm{K} 4),(\mathrm{K} 1 / \mathrm{K} 5)$

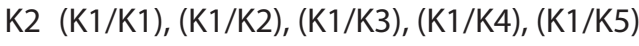


$\mathrm{K} 3 \otimes(\mathrm{K} 1 / \mathrm{K} 1),(\mathrm{K} 1 / \mathrm{K} 2),(\mathrm{K} 1 / \mathrm{K} 3),(\mathrm{K} 1 / \mathrm{K} 4),(\mathrm{K} 1 / \mathrm{K} 5)$

$\mathrm{K} 4 \bigotimes(\mathrm{K} 1 / \mathrm{K} 1), \quad(\mathrm{K} 1 / \mathrm{K} 2),(\mathrm{K} 1 / \mathrm{K} 3),(\mathrm{K} 1 / \mathrm{K} 4),(\mathrm{K} 1 / \mathrm{K} 5)$

$\mathrm{K} 5 \bigotimes(\mathrm{K} 1 / \mathrm{K} 1),(\mathrm{K} 1 / \mathrm{K} 2),(\mathrm{K} 1 / \mathrm{K} 3),(\mathrm{K} 1 / \mathrm{K} 4),(\mathrm{K} 1 / \mathrm{K} 5)$

\{Penentuan bobot keseluruhan \}

Endfor

For $\mathrm{i}=1$ to 4

Bobot pemilihan $\otimes$ Total jumlah nilai kriteria

Endfor

Jumlah elemen kriteria

\{Membuat nilai Max konsistensi \}

Max $\otimes$ total

For $\mathrm{i}=1$ to 4

Max $\otimes($ Total matriks perbandingan kriteria * nilai bobot perioritas

keseluruhan )

Endfor

Index konsistensi \max - jumlah kriteria

\{ Membuat rasio konsistensi \}

$$
\text { Jumlah kriteria -1 }
$$

If

Jumlah kriteria $=$ ukuran matriks then

Nilai ukuran matriks $\bigotimes$ ukuran matriks

Rasio konsistensi $\bigotimes$ index konsistensi

Nilai ukuran matriks

\{ Tahap Pemilihan Texapon / SPK \}

Nilai bobot $\nabla$ bobot texapon * bobot perioritas kriteria

Nama Texapon $\otimes T e x a p o n$ yang bobotnya masksimum

\subsection{Implementasi Sistem}

\section{Menu Input Data Alternatif}

Tampilan berikutnya dari menu adalah menu input data alternatif, menu ini merupakan tampilan berguna untuk melakukan penginputan data alternatif. Tampilan Awal dapat dilihat pada Gambar 1.

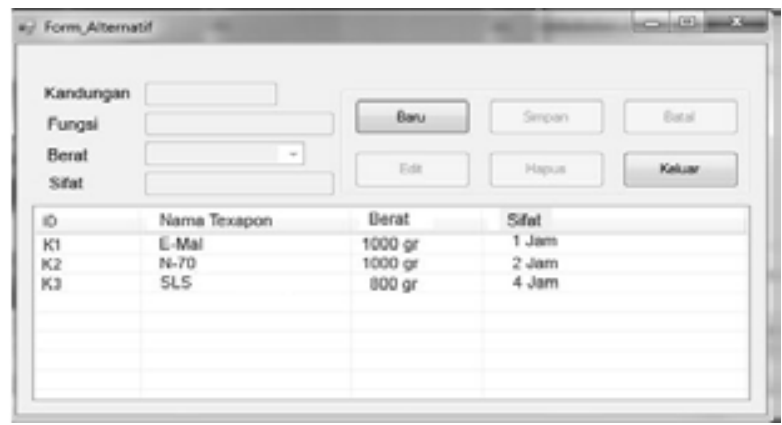

Gambar 1. Menu Input Data Alternatif

Keterangan :

1. Simpan, yang berfungsi untuk melakukan penyimpanan terhadap data yang telah diinputkan.

2. Tambah, adalah untuk melakukan penginputan data yang baru

3. Ubah, adalah untuk melakukan edit atau pengubahan terhadap data yang telah diinputkan.

4. Hapus, adalah untuk melakukan proses penghapusan terhadap data yang salah atau tidak penting

5. Keluar, adalah untuk kembali ke menu utama.

\section{Menu Input Data Kriteria}

Tampilan berikutnya dari menu adalah menu input data kriteria, menu ini merupakan tampilan berguna untuk melakukan penginputan data kriteria. Tampilan Awal dapat dilihat pada Gambar 2 


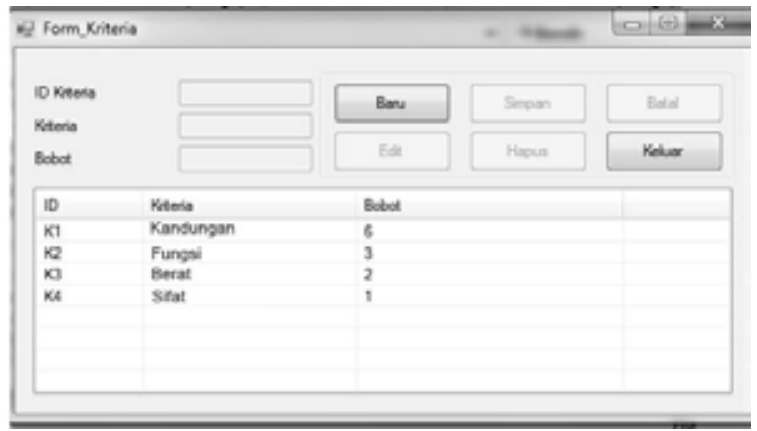

Gambar 2. Menu Input Data Keriteria

Keterangan

1. Simpan, yang berfungsi untuk melakukan penyimpanan terhadap data yang telah diinputkan.

2. Tambah, adalah untuk melakukan penginputan data yang baru

3. Ubah, adalah untuk melakukan edit atau pengubahan terhadap data yang telah diinputkan.

4. Hapus, adalah untuk melakukan proses penghapusan terhadap data yang salah atau tidak penting

5. Keluar, adalah untuk kembali ke menu utama.

\section{Menu Input Data Pembobotan}

Tampilan berikutnya dari menu adalah menu input data pembobotan, menu ini merupakan tampilan berguna untuk melakukan penginputan data pembobotan. Tampilan Awal dapat dilihat pada Gambar 3

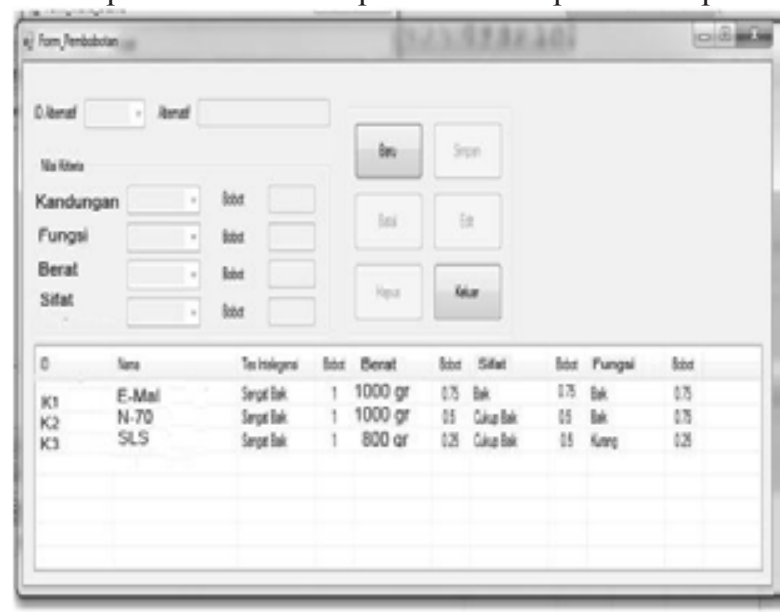

Gambar 3. Menu Input Data Pembobotan

Keterangan :

1. Simpan, yang berfungsi untuk melakukan penyimpanan terhadap data yang telah diinputkan.

2. Tambah, adalah untuk melakukan penginputan data yang baru

3. Ubah, adalah untuk melakukan edit atau pengubahan terhadap data yang telah diinputkan.

4. Hapus, adalah untuk melakukan proses penghapusan terhadap data yang salah atau tidak penting

5. Keluar, adalah untuk kembali ke menu utama.

\section{Menu Input Data Proses AHP}

Tampilan berikutnya dari menu adalah menu input data pembobotan, menu ini merupakan tampilan berguna untuk melakukan penginputan data proses ahp. Tampilan Awal dapat dilihat pada Gambar 4 


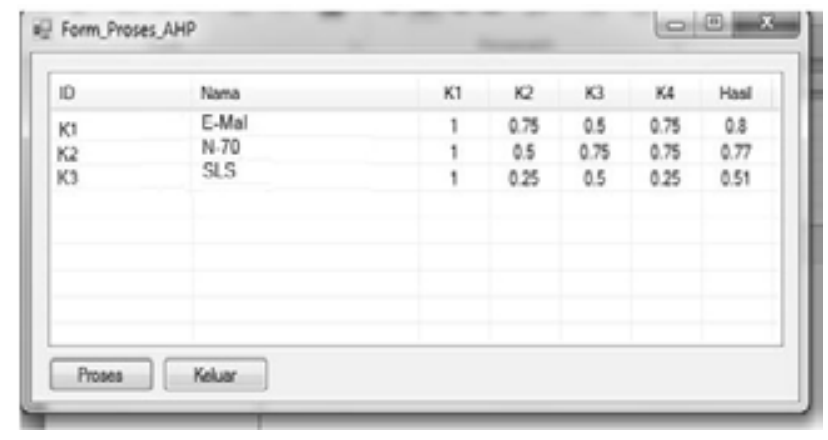

Gambar 4. Menu Input Proses AHP

Keterangan :

1. Proses, adalah untuk memproses data dengan metode ahp.

2. Keluar, adalah untuk kembali ke menu utama.

\section{Kesimpulan}

Dari hasil penelitian ini penulis dapat menarik beberapa kesimpulan yang terkait dengan proses penelitian maupun dengan isi dari penelitian itu sendiri.

1. Telah dapat dibangun suatu sistem pengambilan keputusan dengan menggunakan metode analytical hierarchy process untuk menentukan urutan prioritas dalam pemilihan texapon dalam pembuatan sabun cair.

2. Dengan memanfaatkan beberapa fasilitas yang tersedia pada komputerisasi sistem pengambilan keputusan pemilihan texapon dalam pebuatan sabun cair bisa diaplikasikan dengan berbasis komputer.

3. Pengujian dengan menggunakan aplikasi Visual Basic 2008 dapat bekerja dengan maksimal tetapi masih membutuhkan waktu beberapa saat hingga memperlihatkan hasil proses pemilihan texapon dalam pebuatan sabun cair.

\section{Referensi}

[1]. L Saaty, Thomas, "Analytical Hierarchy Prosess" , Saaty, New York, (2001).

[2]. Suryadi, Kafarsyah, Ali Rahmadani, "Analytical Hierarchy Prosess", 2010, Diakses pada 20 Mei 2015, dari perpustakaan digital.

[3]. Widodo Pudjo, Prabowo, Herlawati, "Menggunakan UML (Unified Modelling Language)", Penerbit Informatika, Bandung, 2011.

[4]. Kusrini, "Tuntunan Membangun Sistem Informasi Dengan VB Dan Microsoft SQL Server", 2 007. Diakses pada 20 Mei 2015, dari perpustakaan digital.

[5]. Asnawi, Zaenudin, "Pembutan Sabun Cair" , Vol 6, 2011, dari; https://Peluang Usaha .com/2011/ 10/01-E-BookPeluang-Usaha-feb-2011.pdf 